\title{
KEDUDUKAN DOKTRIN RES IPSA LOQUITUR (DOKTRIN YANG MEMIHAK PADA KORBAN) DALAM TATA HUKUM INDONESIA
}

\author{
TITIN APRIANI
}

\author{
Program Studi Hukum Kampus Mataram UNMAS Denpasar
}

e-mail: titinapriani97@yahoo.com

\begin{abstract}
ABSTRAK
Penelitian ini merupakan penelitian pustaka dengan menggunakan data berupa buku-buku, undangundang, artikel, jurnal dan literatur lain yang berkaitan denga penelitian ini, sedangkan teknik dan pengumpulan data dengan mengumpulkan berbagai ide, teori dan konsep dari berbagai literatur yang menitik beratkan pada proses perbandingan antara dalil-dalil atau undang-undang lainnya. Hasil penelitian dapat ditarik suatu kesimpulan bahwa doktrin res ipsa loquitur dapat diberlakukan di Indonesia melalui alat bukti persangkaan yang disimpulkan oleh hakim, sesuai dengan aturan hukum yang berlaku. Pasal 173 RIB menyebutkan bahwa dugaan yang tidak berdasarkan kepada suatu perundang-undangan yang berlaku, hanya boleh diperhatikan oleh hakim dalam menjatuhkan putusannya, jika dugaan-dugaan itu penting, seksama, tertentu dan sesuai satu sama lain. Senada dengan Pasal 1922 KUH Perdata menyebutkan bahwa, persangkaan-persangkaan yang tidak berdasarkan undang-undang diserahkan kepada pertimbangan dan kewaspadaan hakim, yang mana itu tidak boleh diperhatikan persangkaan-persangkaan lain, selain yang penting teliti dan tertentu, dan sesuai satu sama lain.
\end{abstract}

Kata kunci : Doktrin Res Ipsa Loquitor, tata hukum Indonesia

\section{ABSTRACT}

This research is a library research that uses data in the form of books, laws, articles, journals and other literature related to the title, while the technique and data collection is by collecting various ideas, theories and concepts from various literatures that focus on the process of comparison between the arguments or other laws. The results of the study can be drawn a conclusion that the doctrine of res ipsa loquitur can be applied in Indonesia through the evidences that have been concluded by the judge, in accordance with applicable law. Article 173 of the RIB states that the allegations which are not based on an applicable law, may only be considered by the judge in passing the verdict, if the allegations are important, thorough, certain and in accordance with one another. In line with Article 1922 of the Civil Code, it is stated that the allegations that are not based on the law are left to the consideration and alertness of judges, which should not be considered by other allegations, other than those that are thorough and certain, and in accordance with each other.

Keywords: Doctrine of Res Ipsa Loquitor, Indonesian legal system

\section{PENDAHULUAN}

\section{Latar belakang}

Penting untuk diketahui bagaimana kedudukan doktrin res ipsa loquitur dalam tata hukum Indonesia, mengingat kajian tentang res ipsa loquitur ini termasuk kajian dibidang hukum acara, khususnya hukum pembuktian yang merupakan bagian dari hukum publik. Karena merupakan hukum publik yang bersifat memaksa (dwingen), maka tentu tidak semata-mata dapat diterapkan kaidah hukum apapun, tanpa alas hukum yang jelas dalam perundang-undangan yang berlaku.

Sebagai suatu gugatan perdata, maka tentu saja pihak yang mengajukan gugatan perdata, dalam hal ini pihak korban yang melakukan perbuatan melawan hukum harus membuktikan banyak hal, termasuk membuktikan adanya kesalahan dari pelaku jika perbuatan melawan hukum tersebut merupakan kelalaian atau kesengajaan. Pembuktian ini sering kali tidak mudah dilakukan dikarenakan tidak selalu mudah untuk mendatangkan saksi-saksi atau alat bukti lain untuk membuktikan adanya suatu perbuatan melawan hukum 
tersebut. Untuk itulah sudah sejak lama hukum memperkenalkan doktrin res ipsa loquitur yang membantu pihak korban (penggugat) untuk membuktikan kasusnya tersebut. Dengan demikian doktrin res ipsa loquitur sebenarnya juga termasuk ke dalam wilayah kajian hukum pembuktian perdata, meskipun sebenarnya penerimaan doktrin res ipsa loquitur ke dalam perbuatan kelalaian tidak dapat hanya dengan dipresumsi, tetapi harus dibuktikan.

\section{Rumusan Masalah}

1. Bagaimana kedudukan doktrin res ipsa loquitur dalam tata hukum Indonesia

2. Bagaimanakah konsekuensi yuridis apabila doktrin res ipsa loquitur diberlakukan atau diterapkan dalam tata hukum Indonesia.

\section{Tujuan dan Manfaat Penelitian}

Tujuan penelitian ini adalah :

a. Untuk mengetahui kedudukan sebuah doktrin res ipsa loquitur dalam tatanan hukum di Indonesia seiring dengan perkembangan hukum yang berlaku.

b. Untuk mengetahui apakah konsekuensi yuridis dari sebuah doktrin res ipsa loquitur apabila dalam hukum yang ada di Indonesia diterapkan doktrin tersebut.

Diharapkan hasil penelitian ini dapat bermanfaat sebagai berikut :

a. Hasil penelitian ini mampu menyumbangkan pemikiran bagi pengembangan ilmu hukum pada umumnya dan pada khususnya di bidang hukum keperdataan.

b. Memperkaya referensi dan literatur dalam dunia kepustakaan tentang kedudukan sebuah doktrin yang diterapkan oleh hakim atau para penegak hukum serta bagaimana konsekuensi yuridis yang terjadi.

c. Dapat mengembangkan kemampuan berpikir dan diharapkan hasil dari penelitian ini dapat digunakan sebagai bahan pertimbangan Pemerintah Indonesia supaya lebih meningkatkan kualitas aturan hukum yang akan diterapkan oleh para penegak hukum atau hakim pada kasus tertentu.

\section{METODE PENELITIAN}

Penelitian ini merupakan penelitian normatif yaitu penelitian yang mengkaji dan menganalisis tentang peraturan perundang-undangan maupun peraturan lain yang ada hubungannya dengan permasalahan di atas. Dalam melakukan penelitian normatif ini menggunakan peraturan perundang-undangan, teori hukum, pendapat hukum dari para ahli hukum. Dalam penelitian ini yang digunakan sebagai acuan adalah Kitab Undang Undang Hukum Perdata khususnya Buku Keempat KUHPerdata yang mengatur mengenai pembuktian dan daluarsa, selain KUHPerdata masalah pembuktian perkara perdata di Indonesia juga diatur dalam Reglemen Indonesia yang dibaharui Staatsblad 1941, Nomor 44 (RIB) dan di dalam Reglement Buiten Gewesten (RBG) atau Reglement Daerah Sebrang (RDS). Perlu diketahui bahwa HIR atau RBG atau RDS diperuntukkan di luar Jawa dan Madura. Pembuktian dalam buku keempat KUHPerdata adalah aspek materiil dari hukum acara perdata, sedangkan pembuktian dalam RIB dan RDS mengatur aspek formil dari hukum acara perdata.

Penelitian ini menggunakan data primer dan sekunder. Data primer mednggunakan Kitab UndangUndang Hukum Perdata, dan Reglemen Indonesia yang dibaharui Staatsblad 1941, Nomor 44 (RIB) dan di dalam Reglement Buiten Gewesten (RBG) atau Reglement Daerah Sebrang (RDS). dan data sekunder, bedrumber dari buku-buku, artikel, majalah, koran, makalah dan lain sebagainya khususnya yang berkaitan dengan penelitian hukum ini; serta Bahan hukum tersier, yaitu bahan hukum yang memberikan petunjuk atau penjelasan terhadap bahan hukum sekunder yang terdiri dari kamus, dan bahan-bahan dari internet.

\section{HASIL DAN PEMBAHASAN}

\section{Kedudukan Doktrin Res Ipsa Loquitur dalam Tata Hukum Indonesia}

Doktrin res ipsa loquitur dalam bahasa Inggris berarti the thing speaks for itself, terjemahan harfiahnya "benda tersebut yang berbicara". Doktrin ini dalam hukum perdata hanya relevan dan berlaku untuk kasus perbuatan melawan hukum dalam bentuk kelalaian (negligence) dan tidak berlaku untuk perbuatan melawan 
hukum dalam bentuk "kesengajaan" atau "tanggung jawab mutlak. Doktrin ini merupakan doktrin pembuktian dalam hukum perdata yang membantu pihak korban (Penggugat) untuk membuktikan kasusnya. Di dalam pembuktian dalam hukum perdata, pihak yang mengajukan gugatan harus membuktikan kesalahan dari pelaku, jika merupakan kelalaian maupun kesengajaan. Pembuktian ini seringkali sangat menyulitkan korban untuk membuktikan bahwa terdapat kelalaian pelaku sehingga terjadi perbuatan melawan hukum yang merugikan korban.

Menurut Munir Fuady (2002) pihak korban dari suatu perbuatan melawan hukum dalam bentuk kelalaian dalam kasus-kasus tertentu tidak perlu membuktikan adanya unsur kelalaian dari pihak pelaku, akan tetapi cukup dengan menunjukkan fakta yang terjadi dan menarik sendiri kesimpulan bahwa pihak pelaku kemungkinan besar melakukan perbuatan melawan hukum tersebut, bahkan tanpa perlu menununjukkan bagaimana pihak pelakunya berbuat sehingga menimbulkan perbuatan melawan hukum tersebut. Doktrin ini sebenarnya merupakan semacam bukti sirkumstansial (circumstantial evidence), yakni suatu bukti tentang fakta dari fakta-fakta mana suatu kesimpulan yang masuk akal ditarik. Misalkan saja dari letak mobil atau kerusakan mobil dapat ditarik kesimpulan kecepatan mobil yang bersangkutan. Atau misalkan seseorang yang jatuh atau cedera karena eskalator tiba-tiba berhenti di suatu hotel atau tempat lain, menurut kelaziman hal ini tidak akan terjadi jika tidak terdapat kelalaian, dalam hal ini doktrin ini dianggap terbukti.

Doktrin res ipsa loquitur diterapkan di Inggris sejak 1809, yaitu dalam kasus terkenal Christie v. Grigg yang menerapkan doktrin tersebut dalam kasus kelalaian pengangkut orang terhadap penumpangnya. Tujuan sebenarnya doktrin ini bukan untuk membalikkan beban pembuktian dan juga bukan untuk mengubah kriteria tanggung jawab, akan tetapi semata-mata bertujuan untuk mempermudah korban dalam hal membuktikan siapa yang bersalah, dengan menunjukkan kepada bukti sirkumstansial. Kadangkala korban dalam kasus-kasus tertentu sangat sulit membuktikan unsur kelalaian dari pihak pelaku, apalagi bukti-bukti berada atau dalam akses dan kekuasaan pelaku yang sulit didapatkan oleh korban.

Kesulitan membuktikan perbuatan melawan hukum dapat diatasi dengan menggunakan titik tolak dalam prinsip hukum fakta yang berbicara sehingga tidak perlu dibuktikan lagi. Jadi di sini berlaku praduga bersalah (presumption of fault or negligence). Mengingat kejadian tersebut tidak akan terjadi dalam keadaan normal tanpa adanya kealpaan pihak-pihak yang berkompeten. Dengan demikian doktrin res ipsa loquitur berjalan seiring dengan doktrin pembuktian terbalik (omkering van bewijslast) dan juga dengan doktrin tanggungjawab mutlak (strict liability), meskipun diantara ketiga doktrin tersebut sebenarnya mengandung perbedaan.

Seperti telah dijelaskan bahwa berdasarkan doktrin res ipsa loquitur seorang korban dari perbuatan melawan hukum dengan unsur kelalaian, dapat menarik kesimpulan bahwa telah terjadi suatu perbuatan melawan hukum meskipun tidak mengetahui siapa persisnya yang melakukan dan dengan cara bagaimana perbuatan tersebut dilakukan. Akan tetapi agar dapat diterapkan doktrin res ipsa loquitur, sehingga kesimpulan dapat ditarik dari suatu fakta yang sebenarnya merupakan presumsi bersalah terhadap pihak pelakunya, ilmu hukum memberikan beberapa persyaratan sebagai berikut:

a. Harus ditunjukkan bahwa kejadian tersebut biasanya tidak terjadi tanpa adanya kelalaian (atau kesengajaan)dari pihak pelakunya.

b. Harus ditunjukkan pula bahwa kerugian tidak ikut disebabkan oleh tindakan korban atau pihak ketiga.

c. Dalam kasus-kasus tertentu, pada saat kejadian, instrument yang menyebabkan kerugian dalam control yang eksklusif dari pihak yang dituduh pelakunya.

d. Penyebab kelalaian tersebut haruslah dalam lingkup kewajiban yang ada oleh pelaku kepada korban.

e. Bukan kesalahan dari korban (atau tidak ada kelalaian kontributif.

Selain dari lima syarat seperti tersebut di atas, maka juga layak untuk dipertimbangkan apakah pembuktian atas kejadian tersebut lebih gampang diakses oleh pihak pelaku dari pihak korban. Tentang persyaratan harus dibuktikan bahwa pada saat kejadian, instrument yang menyebabkan kerugian dalam control yang eksklusif dari pihak yang dituduh pelakunya, dalam banyak hukum modern persyaratan tersebut tidak terlalu ketat. Jika sebelumnya ditekankan bahwa instrument tersebut "sepenuhnya dikontrol" oleh pihak pelaku perbuatan melawan hukum, maka dalam banyak hukum modern pihak korban cukup membuktikan bahwa "kemungkinan besar" kelalaian dilakukan oleh pihak yang dituduh pelaku. Karena itu doktrin res ipsa loquitur biasanya tidak diterapkan terhadap kasus kejadian dimana penyebabnya tidak dalam keadaan bersalah, sepertikematian yang disebabkan oleh tumbangnya pohon.

Di samping itu kebiasaan dari pelaku dapat pula dipakai sebagai pedoman bagi penerapan doktrin res ipsa loquitur. Misalnya kebiasaan pelaku untuk bertindak ceroboh terhadap orang lain. Sehingga besar kemungkinan dalam kasus yang sedang terjadi dia akan mengulangi sikap ceroboh tersebut. Dalam hal ini pihak korban cukup menunjuk bahwa dia memang punya sikap yang ceroboh tersebut. Tanpa perlu 
membuktikan bahwa memang dia yang sebenarnya melakukan tindakan yang tergolong perbuatan melawan hukum tersebut.

Namun demikian, kajian terhadap doktrin res ipsa loquitur secara historis menunjukkan bahwa penerapan doktrin ini banyak dilakukan terhadap pihak-pihak pelaku perbuatan tertentu yang menuntut tingkat kehati-hatian yang tinggi. Dalam sejarah hukum doktrin res ipsa loquitur paling sering diterapkan terhadap pihak perusahaan pengangkutan umum, khususnya yang mengangkut manusia, seperti terhadap perusahaan pengangkutan dengan kapal laut, bus umum, kereta api dan lain-lain, yang memang sangat diharapkan untuk melaksanakan pekerjaan dengan tingkat kehati-hatian yang sangat tinggi. Hampir setiap kasus dalam bidang-bidang tersebut, misalnya jika terjadi kecelakaan umumnya mereka dapat dituding sebagai pelaku perbuatan melawan hukum tanpa perlu membuktikan kesalahannya, akan tetapi cukup dengan menunjukkan adanya peristiwa kecelakaan tersebut dan pihak korban mengalami kerugian tertentu. Sebaliknya kepada pihak pengangkutan dibebankan beban pembuktian bahwa dia sebenarnya dalam keadaan tidak bersalah (tidak lalai).

\section{Konsekuensi Yuridis Apabila Doktrin Res Ipsa Loquitur Diberlakukan atau Diterapkan Dalam Tata Hukum Indonesia}

Apabila doktrin res ipsa loquitur diterapkan maka akan membawa beberapa konsekuensi yuridis sebagai berikut:

a. Lebih memberikan rasa keadilan

Dirasakan sangat tidak adil manakala pihak korban dari perbuatan melawan hukum harus menaggung sendiri suatu kerugian yang sebenarnya merupakan akibat dari kelalaian dari orang lain, hanya karena pihak lain tersebut yang sebenarnya lebih banyak mengetahui kejadiannya, akan tetapi tidak mau menjelaskan apa yang sebenarnya terjadi. Sementara pihak korban memang tidak mengetahui kejadiannya yang persis karena tidak memiliki akses kepada kejadian tersebut, sehingga di pengadilan tidak bisa membuktikan kesalahan pelaku perbuatan melawan hukum tersebut. Ketidak adilan karena terbentur tembok hukum pembuktian ini diterobos dengan memperkenalkan doktrin res ipsa loquitu, yakni dengan memindahkan beban pembuktian (pembelaan tidak bersalah) kepada pihak pelaku perbuatan, sementara pihak korban tidak perlu membuktikan kesalahan pelaku, tetapi cukup membeberkan akibat yang terjadi terhadapnya dan bagaimana sampai akibat tersebut terjadai, serta membuktikan bahwa biasanya akibat seperti itu baru terjadi jika ada kelalaian (atau kesengajaan) dari pihak pelaku perbuatan melawan hukum tersebut.

$b$. Merupakan presumsi kelalaian.

Dengan diberlakukannya doktrin res ipsa loquitur tersebut, maka terjadilah suatu presumsi kelalaian, artinya dengan hanya membeberkan suatu akibat dan fakta yang menimbulkan akibat tersebut, oleh hukum telah dipresumsi bahwa pihak yang disangka pelaku perbuatan melawan hukum dianggap telah melakukannya dengan kelalaian (atau kesengajaan), tanpa korban perlu membuktikan kelalaian (atau kesengajaan) tersebut. Dengan demikian beban pembuktian bahwa pihak pelaku tidak bersalah ada pada pundak pelakunya sendiri, karena pihak pelakulah yang banyak mengetahui tentang hal ihwal terjadinya kejadian tersebut. Sehingga apa yang terjadi sebenarnya adalah semacam pembalikan alat bukti dari pundak korban ke pundak pelaku, atau yang disebut dengan pemberlakuan bukti terbalik (omkering van bewijslast).

c. Menjadi bukti sesuai situasi dan kondisi.

Sesuai dengan namanya bahwa istilah res ipsa loquitur berarti benda tersebut yang berbicara, maka ketika pihak korban membuktikan apa yang dialaminya sehingga menimbulkan kerugian dari fakta, situasi dan kondisi kejadian tersebut dapat ditarik kesimpulan bahwa biasanya kerugian seperti itu terjadi karena adanya kesalahan dari pihak tertentu dalam hal ini oleh hukum dipresumsi sebagai kesalahan pihak yang diduga sebagai pelakunya. Dengan demikian pihak korban hanya membuktikan fakta, situasi dan kondisi (circumstantial evidence) disekitar kejadian yang menimbulkan kerugian tersebut, dengan menarik kesimpulan-kesimpulan tertentu dan membiarkan fakta tersebut sendiri yang berbicara.

d. Memaksa pelaku untuk menjelaskan kejadian yang sebenarnya.

Salah satu pertimbangan mengapa doktrin res ipsa loquitur diberlakukan adalah karena pihak pelaku perbuatan melawan hukum lebih banyak mengetahui dan banyak akses untuk membuktikan apa sebenarnya yang terjadi mengenai kejadian tersebut. Dia pula yang memiliki banyak saksi atau alat bukti lainnya. Karena itu dalam keadaan yang demikian sepantasnyalah jika oleh hukum dia digiring untuk menjelaskan kejadian tersebut dengan cara membebankan pembuktian seandainya dia tidak bersalah.

e. Konsekuensi terhadap pelaku ganda. 
Pemberlakuan doktrin res ipsa loquitur mempunyai dampak khusus bagi perbuatan melawan hukum dengan pelaku ganda atau pelaku salah atu diantara banyak orang, orang mana persisnya tidak diketahui oleh korban. Memang kaidah hukum yang berlaku umum adalah bahwa pihak korban dari perbuatan melawan hukum harus membuktikan siapa diantara banyak orang yang pada kenyataannya melakukan perbuatan melawan hukum tersebut, sehingga kepadanya oleh hukum dibebankan tanggungjawab untuk memberikan suatu ganti kerugian. Akan tetapi dalam kasus-kasus res ipsa loquitur tertentu salah satu atau lebih dari pelaku dapat dimintakan tanggungjawabnya secara hukum, meskipun korban tidak dapat menunjukkan siapa diantara mereka yang bersalah dan melakukan tindakan tersebut. Adalah kewajiban dari pihak yang disangka sebagai pelaku untuk membuktikan bahwa dirinya sebenarnya tidak bersalah atau bahkan tidak melakukan tindakan tersebut.

\section{PENUTUP}

\section{Simpulan}

1. Dalam sistem hukum pembuktian perdata di Indonesia dikenal suatu alat bukti yang disebut dengan alat bukti persangkaan Ada dua macam persangkaan, yaitu persangkaan menurut undang-undang dan persangkaan menurut kesimpulan hakim. Lihat Pasal 1915 KUHPerdata. Pasal 173 RIB menyebutkan bahwa dugaan-dugaan yang tidak berdasarkan kepada suatu perundangn-undangan yang berlaku, hanya boleh diperhatikan oleh hakim dalam menjatuhkan putusannya, jika dugaan-dugaan itu penting, seksama, tertentu dan sesuai satu sama lain. Senada dengan itu Pasal 1922 KUHPerdata menyebutkan bahwa: Persangkaan-persangkaan yang tidak berdasarkan undang-undang diserahkan kepada pertimbangan dan kewaspadaan hakim, yang mana itu tidak boleh diperhatikan persangkaan-persangkaan lain, selain yang penting, teliti dan tertentu, dan sesuai satu sama lain. Dengan adanya beberapa konsekuensi yuridis dari penerapan doktrin res ipsa loquitur tersebut maka para korban atau khusus korban perbuatan melawan hukum akan merasa mendapat suatu perlindungan hukum yang sudah seharusnya atau sewajarnya untuk didapatkan ketika terjadi suatu perbuatan melawan hukum dengan jenis tertentu seperti yang sudah diuraikan diatas.

\section{DAFTAR PUSTAKA}

\section{Buku-buku}

Ahmad Mujahidin. 2007. Peradilan Satu Atap di Indonesia. PT Refika Aditama. Bandung

Bambang Sutiyoso dan Sri Hastuti Puspita Sari. 2005. Aspek-Aspek Perkembangan Kekuasaan.

Kehakiman. UII Press Yogyakarta.

Effendy Maruapey. Sumpah Jabatan Jabatan Didapat Sumpah Dilipat. Forum Hukum.

Fuady Munir, 2013. Perbuatan Melawan Hukum, Pendekatan Kontemporer, Cetakan ke IV PT.Citra Aditiya. Bandung.

Hiariej Eddy O.S, 2012. Teori dan Hukum Pembuktian. Penerbit Erlangga, Ciracas: Jakarta.

Muhammad Abdulkadir, 2000. Hukum Acara Perdata, Penerbit PT. Citra Aditya Bakti, Bandung. Syamsudiin, Aziz. 2009. Tindak Pidana Khusus, Sinar Grafika. Jakarta

Subekti, 1994. Pokok-Pokok Hukum Perdata, PT. Intermasa, Cetakan ke XXVI. Jakarta

Taufik Makarao Moh, 2004. Pokok-Pokok Hukum Acara Perdata, Penerbit: PT. Rineka Cipta. Jakarta

Witanto Y, Keumala Jeumpa Ida, 2013. Hukum Acara Perdata Tentang Ketidak Hadiran Para Pihak

Dalam Proses Berperkara, Cetakan ke 1. PT. Mandar Maju.

\section{B. Undang-Undang}

Kitab Undang-undang Hukum Perdata.

Reglemen Indonesia yang dibaharui Staatsblad 1941, Nomor 44 (RIB).

Reglement Buiten Gewesten (RBG) atau Reglement Daerah Sebrang (RDS). 